\title{
Aquatic beetles (Coleoptera) in springs of a small lowland river: habitat factors vs. landscape factors
}

\author{
J. Pakulnicka ${ }^{1, \star}$, P. Buczyński² ${ }^{2}$ P. Dąbkowski ${ }^{3}$, E. Buczyńska ${ }^{4}$, E. Stępień ${ }^{5}$, R. Stryjecki ${ }^{4}$, \\ A. Szlauer-Łukaszewska ${ }^{3}$ and A. Zawal ${ }^{3}$ \\ 1 Department of Ecology and Environmental Protection, University of Warmia and Mazury, Łódzki Square 3, 10-727 Olsztyn, Poland \\ 2 Department of Zoology, Maria Curie-Skłodowska University, Akademicka 19, 20-033 Lublin, Poland \\ 3 Department of Invertebrate Zoology and Limnology, University of Szczecin, Wasska 13, 71-415 Szczecin, Poland \\ 4 Department of Zoology, Animal Ecology and Wildlife Management, University of Life Sciences, Akademicka 13, 20-033 Lublin, Poland \\ 5 Department of Plant Taxonomy and Phytogeography, University of Szczecin, Waska 13, 71-415 Szczecin, Poland
}

Received March 12, 2016 - Revised May 6, 2016 - Accepted May 12, 2016

\begin{abstract}
We identified the beetle fauna of springs of a small lowland river and attempted to determine the direction and magnitude of beetle migration between the springs and neighboring water bodies in the river valley, as well as the local environmental factors and landscape parameters that most influence the character of aquatic beetle assemblages in the springs. We studied springs of three limnological types, along the entire length of the river valley, and identified 42 beetle species. All types of springs were dominated by stagnobiontic species, which enter springs from other aquatic environments, mainly via dispersion by air. We also found a small proportion of crenophiles and a substantial proportion of rheophiles and tyrphophiles, which was linked to the close proximity of the river and dystrophic water bodies. The fauna of the springs was affected to a similar degree by local environmental factors and by landscape factors acting on a broader scale. This indicates the need for broader consideration of landscape factors, which are often neglected in ecological studies.
\end{abstract}

Key-words: aquatic beetles / river valley / migration / synecological elements / landscape / environmental factors

Résumé - Les coléoptères aquatiques (Coleoptera) des sources d'une petite rivière de plaine : facteurs d'habitat vs. facteurs de paysage. Nous avons identifié la faune des coléoptères des sources d'une petite rivière de plaine et tenté de déterminer la direction et l'ampleur de la migration des coléoptères entre les sources et les plans d'eau voisins dans la vallée, ainsi que les facteurs environnementaux locaux et les paramètres du paysage qui influencent le plus le caractère des assemblages de coléoptères aquatiques dans les sources. Nous avons étudié les sources de trois types limnologiques, sur toute la longueur de la vallée de la rivière, et identifié 42 espèces de coléoptères. Tous les types de sources ont été dominés par des espèces stagnobiontes qui viennent d'autres milieux aquatiques, principalement par dispersion par voie aérienne. Nous avons également constaté une faible proportion de crénophiles et une proportion importante de rhéophiles et tyrphophiles, qui a été reliée à la proximité de plans d'eau et rivières dystrophiques. La faune des sources a été affectée à un degré similaire par des facteurs environnementaux locaux et par des facteurs paysagers agissant sur une plus grande échelle. Cela souligne la nécessité d'un examen plus large des facteurs de paysage, qui sont souvent négligés dans les études écologiques.

Mots-clés : coléoptères aquatiques / rivière / migration / éléments synécologiques / paysage / facteurs environnementaux

\section{Introduction}

The beetle fauna of diverse aquatic environments is very well known, and their communities and typical species have been discussed in original research papers and monographs (e.g., Koch, 1989; Giora, 2014).

^ Corresponding author: joanna.pakulnicka@uwm.edu.pl
Recently interest has been growing in faunistic connections observed in river valleys between the river and other water bodies of its floodplain (Biesiadka and Pakulnicka, 2004; Przewoźny et al., 2005; Pakulnicka and Nowakowski, 2012; Costea et al., 2013). Springs, however, which are the smallest aquatic ecosystems contributing to this system, continue to receive too little attention (Martin and Brunke, 2012; Višinskienė and Bernotienè, 2013) and detailed studies presenting in-depth 


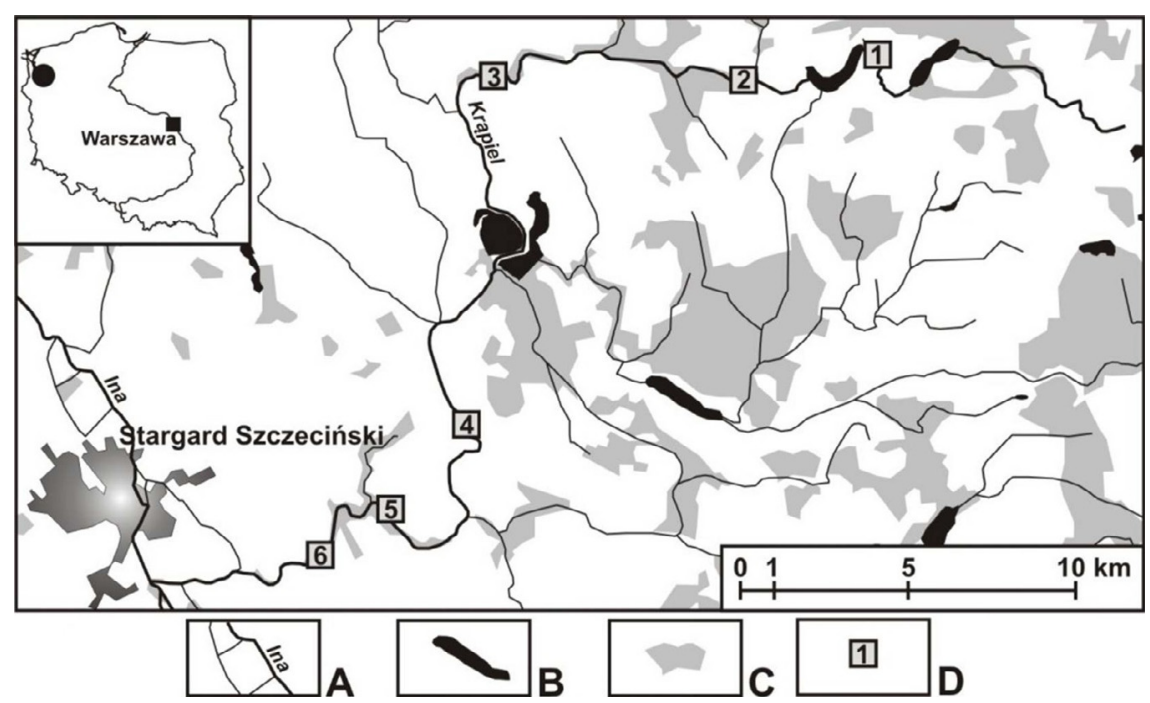

Fig. 1. Study area. A - rivers, B - water bodies, $\mathrm{C}$ - forests, D - sites.

ecological analyses are still lacking. Surprisingly few comprehensive studies have been conducted on the aquatic beetles of springs (e.g. Demel, 1922; Roughley and Larson, 1991; Kordylas, 1994; Pakulnicka, 1999; Czachorowski et al., 2000; Buczyński et al., 2003; Trávníček, 2010; Pakulnicka and Zawal, 2012).

Yet springs are important hydrological elements that give rise to rivers and feed them along their entire course. They also have significant ecological value as habitats with distinctive and naturally stable environmental conditions, inhabited by distinctive fauna (Di Sabatino et al., 2003; Cantonati et al., 2006). However, because they are unique and generally small, they are particularly vulnerable to the anthropogenic transformations taking place in recent years in the ecological landscape, which pollute the groundwater and lower its levels (e.g. Zollhöfer, 1997; Martin et al., 2008; Martin and Brunke, 2012; Pakulnicka and Zawal, 2012). The quality of spring water, which reflects the water quality in the entire hydrological system, is regulated in part by the European Water Framework Directive (Williams and Williams, 1998; Glazier, 2009; Martin and Brunke, 2012), according to which one means of assessing the ecological status of aquatic environments is by monitoring the macroinvertebrates living in it. The importance of aquatic beetles has been emphasized in this context, as they are sensitive to environmental factors and generally react quickly to changes (Eyre et al., 1992; Foster and Eyre, 1992; Winfield Fairchild et al., 2000; Bosi, 2001; Menetrey et al., 2005; Pakulnicka, 2008; Giora et al., 2010; Pakulnicka and Nowakowski, 2012; Pakulnicka et al., 2013, 2015a, 2015b). This is possible due to the considerable dispersal capacity of these insects (Bilton, 1994; Lundkvist et al., 2002), which allows them to move between water bodies that are often far apart, as pointed out by such authors as Biesiadka and Pakulnicka (2004), Pakulnicka and Nowakowski (2012), and Costea et al. (2013) in regard to the hydrological system formed by aquatic environments in a river floodplain.

Many hydrobiologists look for relationships between the structure of beetle fauna and its habitat, emphasizing that they are not well known (Williams et al., 1997; Botosaneanu, 1998;
Hoffsten and Malmqvist, 2000; Smith et al., 2003). Some (e.g., Kubíková et al., 2012; Martin and Brunke, 2012) claim that the character of fauna depends on geomorphology, hydrological characteristics, and abiotic factors, including water chemistry and substrate composition. For biocenoses in springs the proximity of other aquatic environments is important as well (Pakulnicka, 1999). The role of biotic factors, including interspecies interactions, has been emphasized (Juliano and Lawton, 1990a, 1990b; Pakulnicka et al., 2013, 2015a; Frelik, 2014; Frelik and Pakulnicka, 2015). Finally, in recent decades awareness is growing of the importance of factors shaping the landscape, such as geographical location and the type, structure, and use of the landscape, for aquatic environments and the macroinvertebrates inhabiting them (Castella et al., 1991; Delettre et al., 1992; Khmeleva et al., 1994; Richards and Host, 1994; Richards et al., 1996; Pakulnicka, 1999; Delettre and Morvan, 2000; Galic et al., 2013; Zawal et al., 2015a, 2015b). However, studies treating these issues comprehensively and balancing the role of individual groups of factors are still lacking.

We analyzed aquatic beetle fauna in springs situated in the valley of a lowland river, including the quantitative and qualitative structure of the fauna of different types of springs. Next, we used these data to evaluate the direction and magnitude of migration of beetles between springs and other water bodies in the river valley, and attempted to determine what factors - local environmental factors or landscape parameters of the catchment acting on a wider scale - most significantly determine the character of aquatic beetle communities in springs.

\section{Methods}

We conducted the research in six macrohabitats (sampling sites) along the course of a small lowland river, the Krapiel (north-western Poland; Figure 1), whose valley is characterized by many springs and by differing landscape parameters and hydromorphological conditions. Each sampling site was a 
location in the river valley covering an area where springs were situated.

We studied 25 springs (Table 1), collecting faunistic samples in May, July, September, and November 2011. Characterization of the springs included their distance from the river, location in different plant communities, and differentiation of microhabitats: (1) bottom - muddy or sandy, (2) vegetation - overgrown or bare, (3) organic matter - present or absent. Due to the small size of the ecosystems and the risk of destroying them, at each site we collected only one faunistic sample from an area of about $0.25 \mathrm{~m}^{2}$ with a hand net. In the limnocrenes one sample consisted of 10 energetic sweeps, while in the helocrenes and rheocrenes we swept the top layer of the substrate. We collected a combined 34 samples.

We also tested the quality of the habitats, from the catchment level, to the buffer zones and hydromorphological characterization of the river valley, to point values for hydrochemical parameters. Landscape analysis was based on buffer zones and sub-catchments assigned to each sampling site (macrohabitat). The buffer zone was marked out as a circle with a radius of $500 \mathrm{~m}$ around a point defining the sampling site.

The catchment basin of the Krapiel River was divided into segments corresponding to the sampling sites and in this manner a catchment area was assigned to each site.

Buffer zones with a radius of $500 \mathrm{~m}$ from the sampling point were marked out using GPS. Patches with different types of cover were identified in various buffer zones and catchment areas. Land cover classes were determined according to the Corine classification on the basis of various forms of land use (forests, fields, swamps, built-up areas, meadows, shrubs, wasteland, and water bodies). Analysis of the spatial structure of the buffer zones and catchments was based on a set of landscape metrics calculated using TNTmips software by MicroImages. Classification was based on data from Landsat TM7 28-05-2003.

The following measures and indices were used to analyze the landscape structure: (1) measurements of patch area - area (AREA); (2) measurements of patch density and size number of patches (NUMP), mean patch size (MPS), median patch size (MEDPS), patch size standard deviation (PSSD), and patch density (PD); (3) boundary measurements - total edge length (TE), edge density (ED), and mean edge length (MTE); (4) shape measurements - mean shape index (MSI), mean patch fractal dimension (MPFD), and sum of patch shape indices (SUM); (5) diversity and distribution indices - mean distance to nearest neighbor (MNN), Interspersion and Juxtaposition Index (IJI), Shannon's patch diversity index (SDI), the Shannon evenness index (SEI), catchment area from the sources (a cat cu), catchment area (a cat), length of catchment boundaries, roughness $(\mathrm{Ra})$, contagion $(\mathrm{Cr})$, river gradient (river fa), distance from the source (d source), area (a) of each patch (forests, fields, swamps, built-up areas, meadows, shrubs, wasteland, and water bodies), and distance from the river (d) of each patch (forests, fields, swamps, built-up areas, meadows, shrubs, wasteland, and water bodies); (6) characteristics of particular patches (forests, fields, swamps, built-up areas, meadows, shrubs, wasteland, and water bodies) in the buffer zones: area (CA), mean patch size: (MCA), mean shape index (MSI), patch density (PD), and ratio of area to boundary length (L/D); numbers in brackets (1, 2, 3, 11, and 15) designate types of patches (urban fabric, isolated buildings, thoroughfares, deciduous forests, and osiers, respectively). After analyzing the data we selected only landscape parameters shown to have a statistically significant effect on fauna distribution $(p<0.05)$.

For each of the sampling sites we performed a hydromorphological evaluation of the river valley based on the River Habitat Survey (RHS), a standardized method allowing the results to be compared with other studies (Szoszkiewicz et al., 2012). For the needs of our study we modified the RHS method by using segments $100 \mathrm{~m}$ in length instead of $500 \mathrm{~m}$, because the habitats covered by $500 \mathrm{~m}$ segments would be too diverse, making the results more difficult to interpret. We calculated the following indices on the basis of fieldwork (Szoszkiewicz et al., 2012): Habitat Modification Score (HMS), Habitat Quality Assessment (HQA), River Habitat Quality (RHQ), and River Habitat Modification (RHM).

The water parameters - temperature, $\mathrm{pH}$, electrolytic conductivity, and dissolved oxygen content - were measured with an Elmetron CX-401 multiparametric sampling probe; water flow using a SonTek acoustic FlowTracker flowmeter; $\mathrm{BOD}_{5}$ by Winkler's method; and the remaining parameters with a Slandi LF205 photometer. We performed three measurements each time and used the median for further analyses.

We divided the beetle fauna into synecological groups, defined as groups of species with similar habitat preferences: crenophiles, rheobionts and rheophiles, tyrphobionts and tyrphophiles, and stagnobionts. To analyze beetle assemblages we used a dominance index and a frequency index (Trojan, 1978). We used the Kruskal-Wallis test and post hoc multiple comparisons to test the significance of differences in abundances and species richness. We used the Euclidean Similarity Index to calculate similarity between springs according to catchment characterizations, and determined faunistic similarity between sub-sites and sub-catchments by the quantitative Bray-Curtis formula (Bray and Curtis, 1957), using the Simple Average Link method for hierarchical grouping of objects. The results are presented in the form of similarity dendrograms. Similarities between objects were determined using Biodiversity Pro v.2 software (McAleece et al., 1997). We used the Wilcoxon signed-rank test to verify whether the grouping according to the quantitative structure of beetle communities was consistent with the grouping according to the structure of the objects' characteristics (Sokal and Sneath, 1995). All calculations were made in Statistica 12.0 software.

We used Canonical Correspondence Analysis (CCA) (ter Braak, 1986; ter Braak and Verdonschot, 1995) to determine relationships between the occurrence of beetle species and environmental parameters in the water bodies of the Krapiel River valley, after first performing Detrended Correspondence Analysis (DCA). Data for the calculations were not transformed (O'Hara and Koetze, 2010). We considered only features that were not collinear. The calculations were performed in Canoco 4.5. The correlation strength was assessed on a scale commonly used in statistics (Sokal and Rohlf, 1995). 


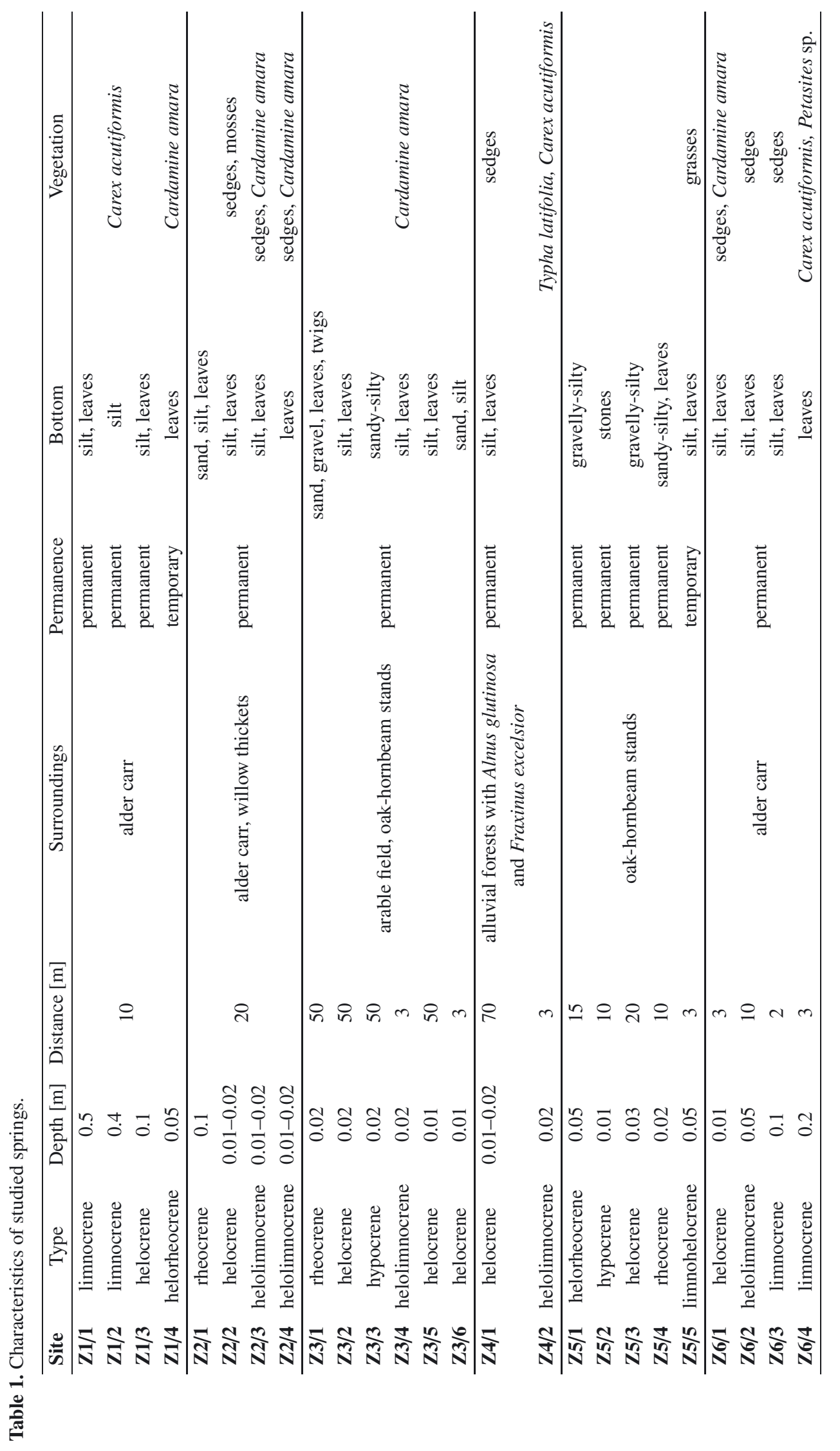




\section{Results}

\subsection{General characterization of the fauna of the springs}

We collected 1112 aquatic beetle individuals (820 larvae and 292 adults) representing 42 species (Table 2). Overall, the qualitatively and quantitatively richest fauna was in the helocrenes (34 species, $45.3 \%$ of specimens caught). We found 28 species in the limnocrenes $(27.3 \%$ of specimens) and 7 in the rheocrenes $(27.4 \%$ of specimens).

Note that we found a tyrphophilic species that is rare in Poland in the springs of the Krapiel: Helophorus pumilio (Przewoźny et al., 2006).

At the level of individual springs, the fauna of the limnocrenes was richest, with an average $60.4 \pm 40.2$ specimens caught (range: 10-97), representing an average $8.6 \pm$ 2.2 species. The fauna of the helocrenes was slightly less rich $(38.8 \pm 16.5,16-77,7.4 \pm 3.3)$, while that of the rheocrenes was much poorer $(2.4 \pm 1.5,1-5,2.4 \pm 1.5)$. Species richness in different types of springs differed significantly (KruskalWallis test: $\mathrm{H}(2, n=23)=11.4, p=0.003)$, including between rheocrenes and helocrenes (multiple measurements $p=$ $0.0045)$ and between limnocrenes and rheocrenes $(p=0.015)$.

Most abundant in the material collected were Scirtes sp. (over half of the material), followed by Prionocyphon serricornis and Dytiscus dimidiatus. Anacaena limbata, Hydrochara caraboides, and Agabus biguttatus were also fairly abundant. The highest frequency was noted for Anacaena limbata, Hydraena palustris, Prionocyphon serricornis, and Scirtes sp., which were present at all the sub-sites. Hydroporus nigrita, Agabus biguttatus, A. bipustulatus, and A. paludosus were also very common.

Groups of species can be distinguished in the collected fauna according to their ecological requirements and range of environmental tolerance. Crenophiles, which were represented in small numbers by Agabus biguttatus (1.8\% of the material), are the most specific to springs. The remaining species can be divided into three groups. The rheophiles were Haliplus fluviatilis, Ilybius fenestratus, I. fuliginosus, and Agabus paludosus (1.9\% of specimens). Tyrphophiles and tyrphobionts were represented by 12 species (5.1\%), of which the most abundant were Acilius canaliculatus, Hydroporus nigrita, and Anacaena lutescens. However, most of the fauna of the springs was stagnobiontic (91.2\%). These numbered 25 species, including argillophiles (of the genus Helophorus) associated with a sand or gravel bottom.

Stagnobionts were quantitatively dominant in all types of springs. They were the only synecological element present in the rheocrenes, dominated mainly by Scirtes sp. All distinguished groups of species were noted in the helocrenes. The crenophile Agabus biguttatus accounted for $2 \%$ of the assemblage here, rheophiles (Agabus paludosus and Ilybius fuliginosus) for $1.2 \%$, and tyrphophiles and tyrphobionts (9 species) for $6.1 \%$. Tyrphophiles and tyrphobionts were fairly abundant in the limnocrenes, with 7 species, the most abundant of which was Acilius canaliculatus, and $7.9 \%$ of the material. Less numerous were rheophiles (4 species, $4.9 \%$ individuals) and crenophiles (1 species, $3.3 \%$ individuals).

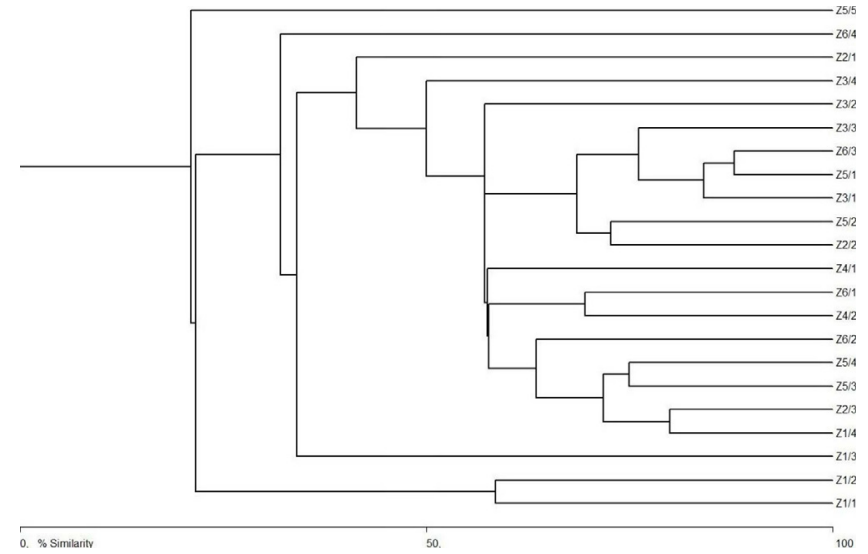

Fig. 2. Faunistic similarity between springs.

\subsection{Faunistic similarity between springs}

Faunistic similarity between springs ranged from $21.1 \%$ to $87.9 \%$ (Figure 2). The springs were clearly grouped in three clusters, with high similarity of about $70 \%$.

The highest similarity $(87.9 \%)$ was noted between springs Z6/3 and Z5/1 (helocrenes) and between Z3/1 (a helocrene) and Z5/1 (a rheocrene; 84.1\%). High similarity (72.7\%) was also noted for Z5/2 (a rheocrene) and Z2/2 (a helocrene). These springs form one cluster. A combined 18 species were found in them, including 6 that were common to at least two springs. The most abundant were Scirtes sp., present in very high numbers in all the springs.

We also noted fairly high similarity (69.6\%) between springs Z4/2 and Z6/1 (helocrenes; cluster 2). A combined 11 species were found here, of which four were common to both springs: Hydroporus nigrita, Anacaena limbata, Limnebius parvulus, and Scirtes sp.

The third cluster consisted of helocrenes Z6/2, Z5/4, Z5/3, $\mathrm{Z} 2 / 3$, and $\mathrm{Z} 1 / 4$. The highest similarity $(80 \%)$ was noted between springs $\mathrm{Z} 2 / 3$ and $\mathrm{Z} 1 / 4$, in which 11 species were recorded, including 8 common to both springs. Prionocyphon serricornis and Scirtes sp. were the most abundant. Somewhat lower faunistic similarity (75\%) was shown between springs $\mathrm{Z} 5 / 4$ and Z5/3. A combined 3 species were noted here, 2 common to both springs, where they were very abundant - Prionocyphon serricornis and Scirtes sp. The limnocrenes $\mathrm{Z} 1 / 1$ and $\mathrm{Z1} / 2$ were faunistically fairly distant from the second and third clusters described above, with similarity of $58.5 \%$. A combined 20 species were noted here, of which 4 were common to both ponds: the very numerous Dytiscus dimidiatus and Hydrochara caraboides and the less abundant Acilius canaliculatus and Ilybius ater.

The clusters of springs formed on the basis of faunistic similarity (Figure 2) were not consistent with the grouping according to landscape characteristics (Wilcoxon test: $Z=0.26$, $p=0.79$ ). Here they are grouped in two blocks differing in degree of landscape fragmentation: 1 - more varied and fragmented landscape and 2 - more homogeneous landscape (Figure 3 ). Of the 25 springs only 7 were grouped in the same way in both diagrams.

The dendrogram of faunistic similarities (Figure 2) between springs is also different from the dendrogram based on 
J. Pakulnicka et al.: Knowl. Manag. Aquat. Ecosyst. (2016) 417, 29

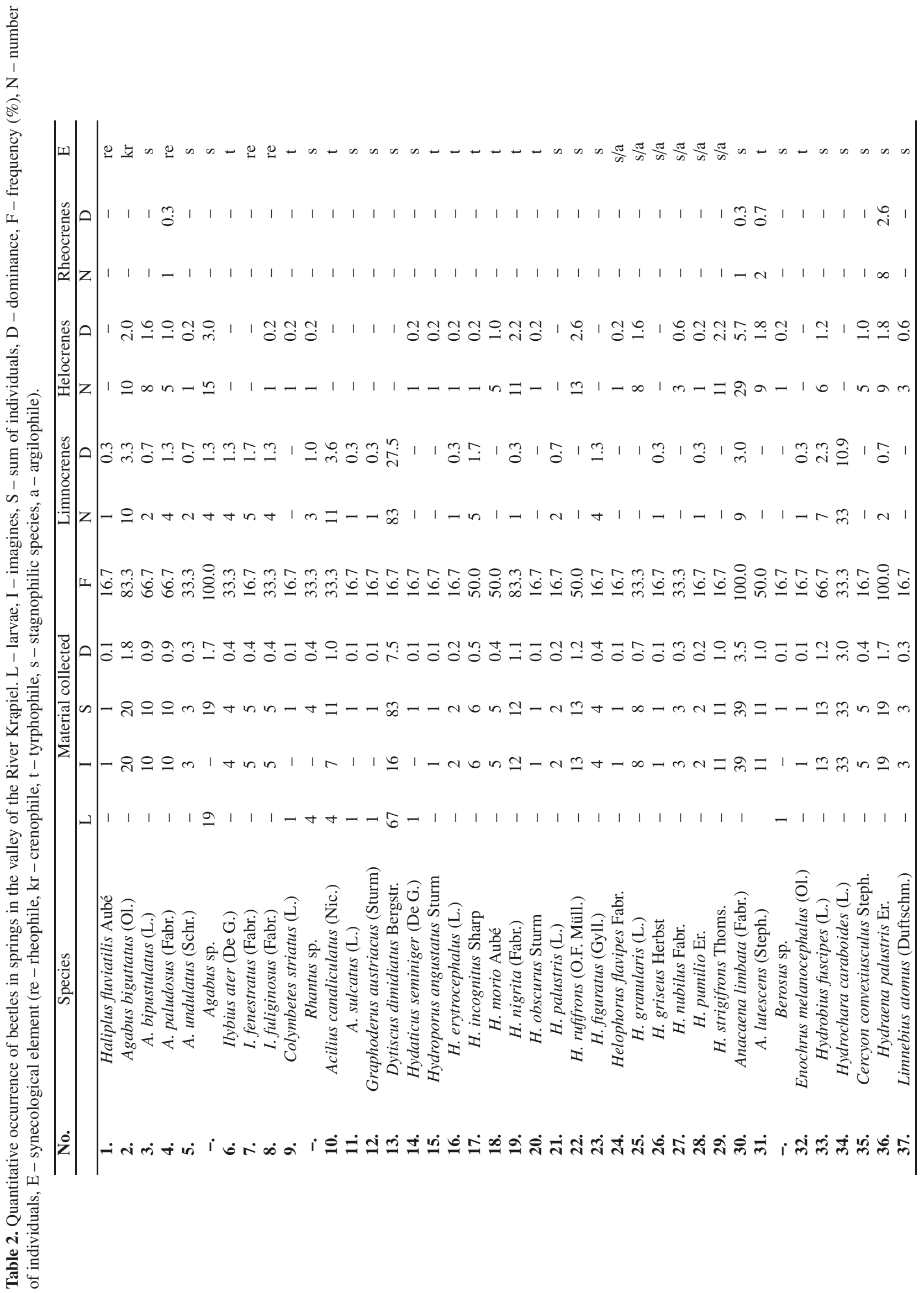



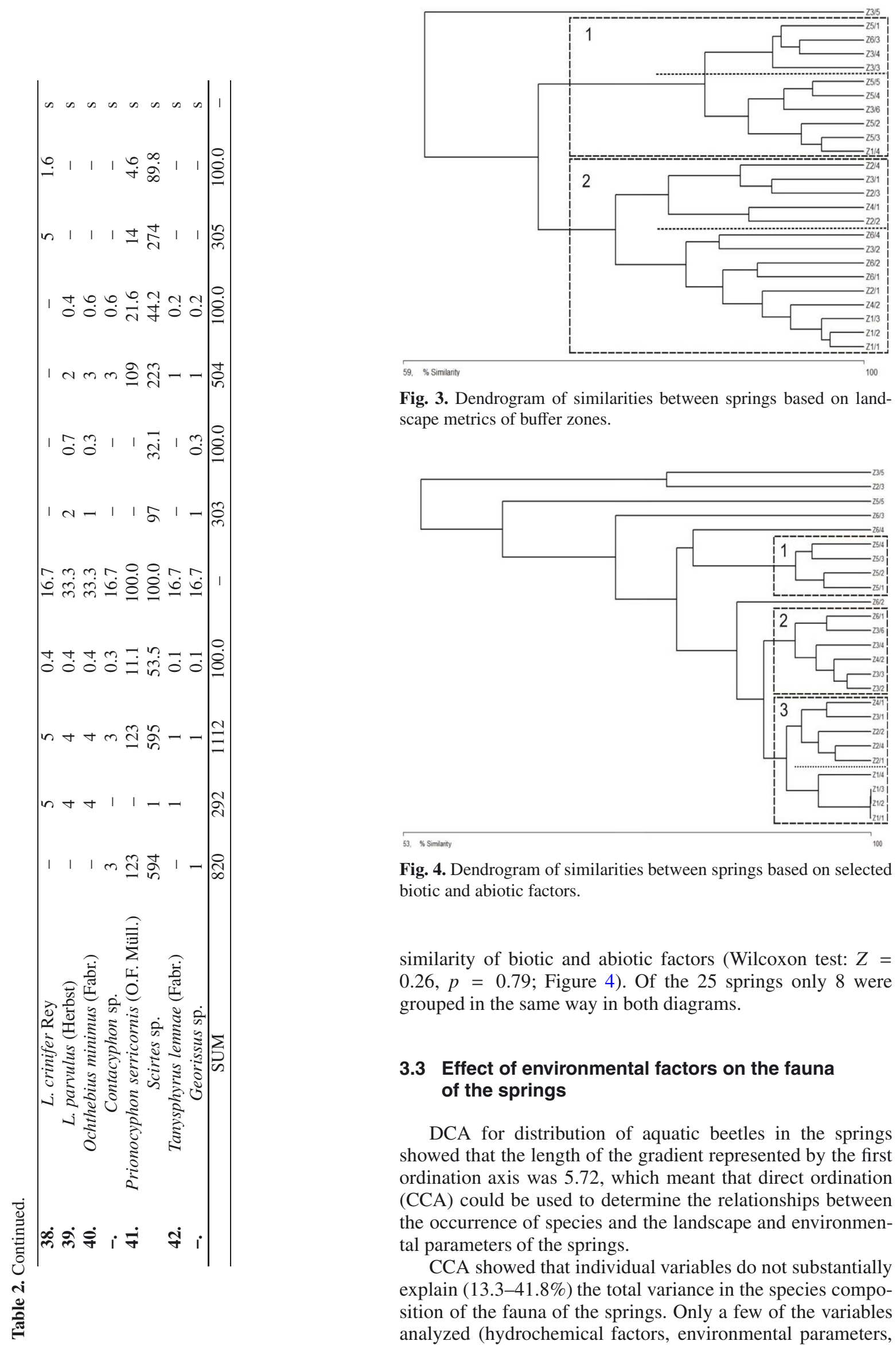

Fig. 3. Dendrogram of similarities between springs based on landscape metrics of buffer zones.

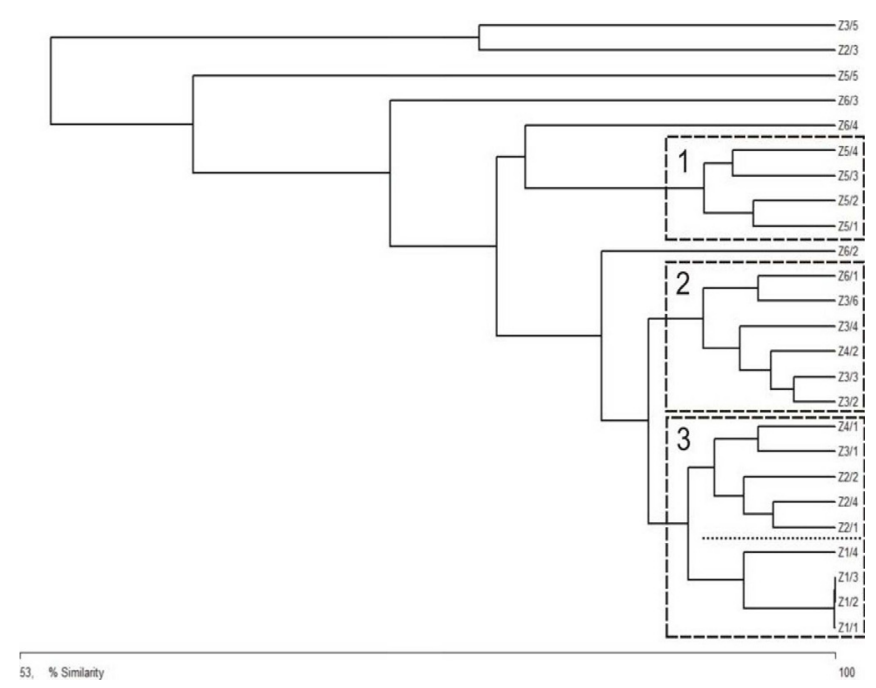

Fig. 4. Dendrogram of similarities between springs based on selected biotic and abiotic factors.

similarity of biotic and abiotic factors (Wilcoxon test: $Z=$ $0.26, p=0.79$; Figure 4 ). Of the 25 springs only 8 were grouped in the same way in both diagrams.

\subsection{Effect of environmental factors on the fauna of the springs}

DCA for distribution of aquatic beetles in the springs showed that the length of the gradient represented by the first ordination axis was 5.72, which meant that direct ordination (CCA) could be used to determine the relationships between the occurrence of species and the landscape and environmental parameters of the springs.

CCA showed that individual variables do not substantially explain (13.3-41.8\%) the total variance in the species composition of the fauna of the springs. Only a few of the variables analyzed (hydrochemical factors, environmental parameters, 


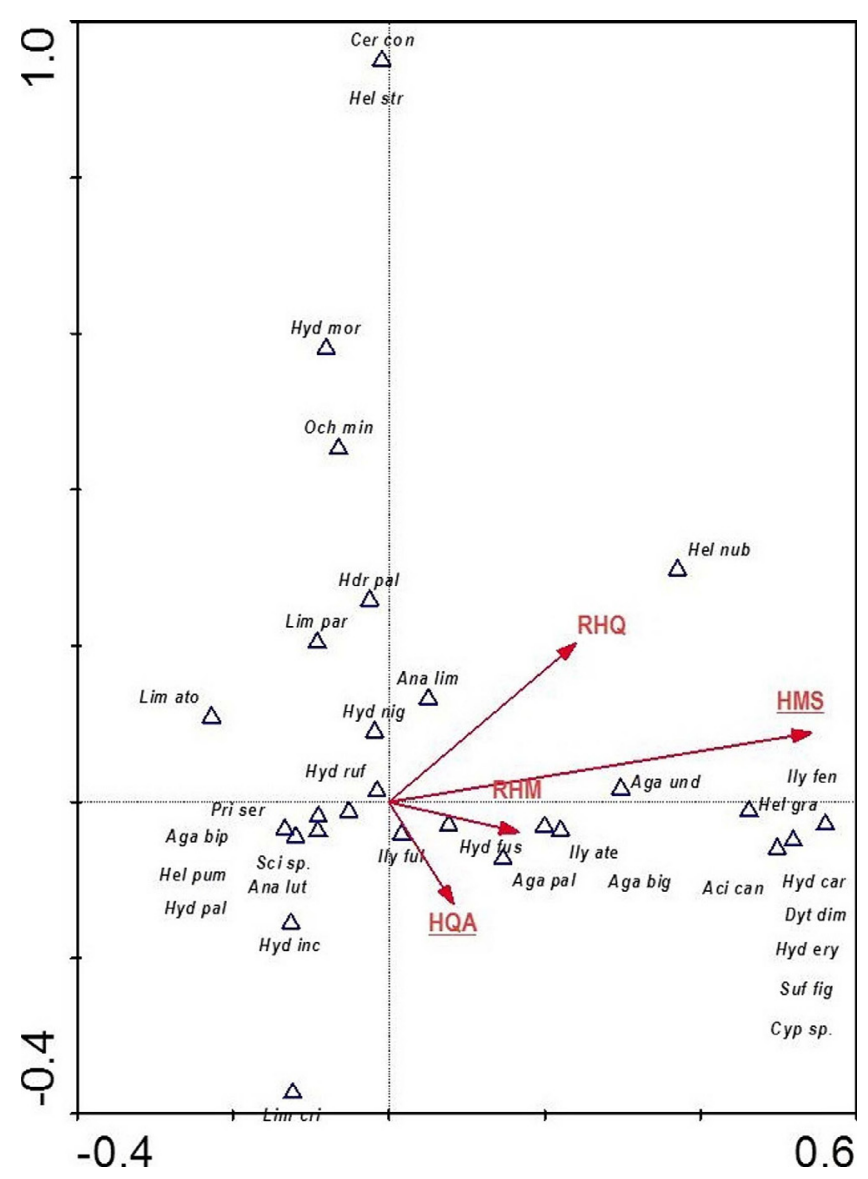

Fig. 5. CCA of the dependence of the occurrence of aquatic beetles on hydromorphological indices of the river channel.

landscape parameters in the buffer zones and in the catchments, and hydromorphological parameters of the river valley) had a statistically significant $(p<0.05)$ effect on fauna characteristics.

The results of direct CCA for the dependence of aquatic beetle distribution on hydromorphological indices of the river channel show that two parameters were statistically significant $(p<0.05)$ : HMS (Habitat Modification Score) and HQA (Habitat Quality Assessment; Figure 5). The variables used in the ordination explain $13.3 \%$ of the total variance in species composition. Only a few stagnobionts showed positive correlations with HMS. Many species, especially those preferring water that is not highly eutrophic, including rheophiles, crenophiles and tyrphophiles, were negatively correlated with HMS (with the strongest correlations for Ilybius fenestratus, Helophorus granularis, and H. nubilus), but positively correlated with HQA.

CCA of the dependence of beetles on the hydromorphological characteristics of the river bed shows that only one parameter was statistically significant: ST (steep bank). It explains $14.8 \%$ of the total variance of beetle species (Figure 6). A fairly heterogeneous group of 17 species was positively correlated with this factor; these represented all synecological elements, mainly larger species that are good swimmers. A negative correlation was noted for beetles that are generally not

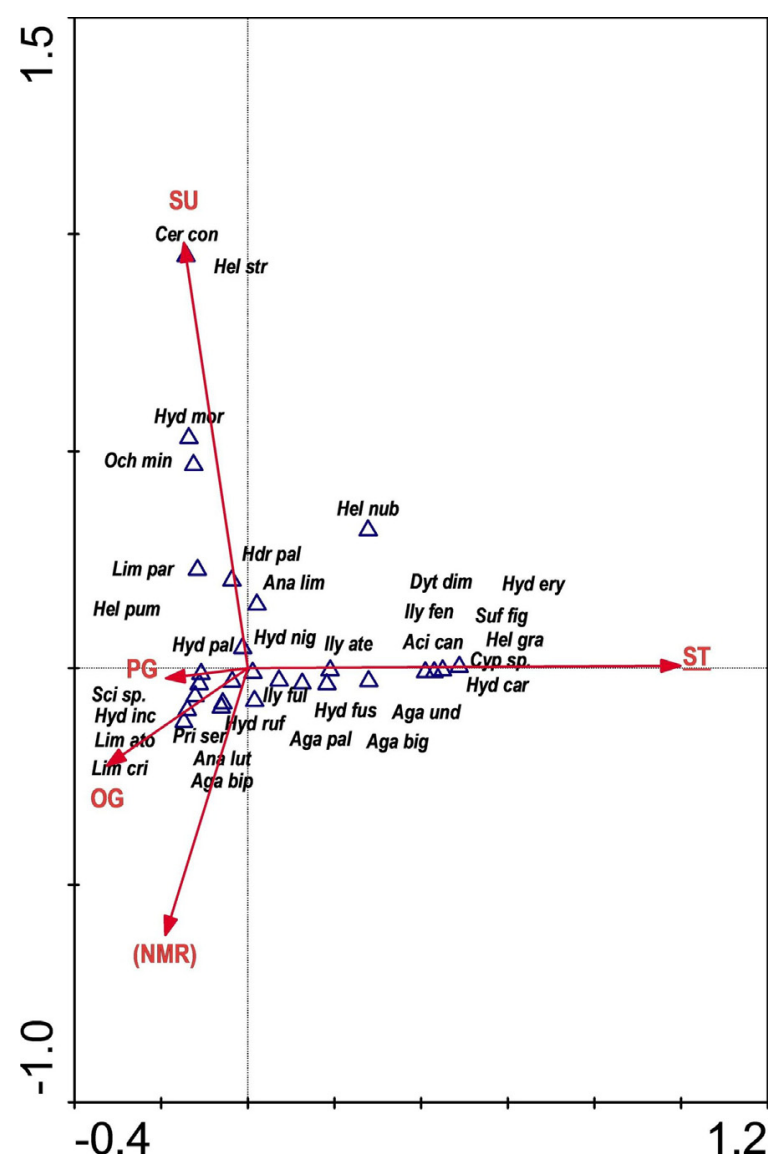

Fig. 6. CCA of the dependence of the occurrence of beetles on hydromorphological characteristics of the river channel.

good swimmers, mainly of the genera Limnebius, Ochthebius, Helophorus, and Scirtes.

CCA for distribution of aquatic beetles according to substrate structure, current velocity, degree of cover by aquatic plants, and insolation show that three variables had a statistically significant effect: plants, organic, and W (sediment sorting). They explain $14.8 \%$ of the total variance in species composition (Figure 7). Most species, particularly stagnobionts, were positively correlated with these factors, with the strongest correlations for Helophorus nubilus, H. granularis, Limnebius parvulus, and Hydroporus figuratus with plants and for Hydroporus palustris with organic, and moderate correlations for Ilybius fenestratus, Acilius canaliculatus, Dytiscus dimidiatus, and Hydrochara caraboides with W.

The results of CCA for beetle distribution according to hydrochemical parameters showed that only one variable $\left(\mathrm{BOD}_{5}\right)$ statistically significantly $(p<0.05)$ explained $21 \%$ of the total variance in species composition (Figure 8 ). This variable is negatively correlated with most species, particularly those preferring less eutrophic water, such as Ilybius fenestratus, Agabus paludosus, Ilybius ater, Hydroporus erytrocephalus, Helophorus nubilus and Agabus biguttatus. 
J. Pakulnicka et al.: Knowl. Manag. Aquat. Ecosyst. (2016) 417, 29

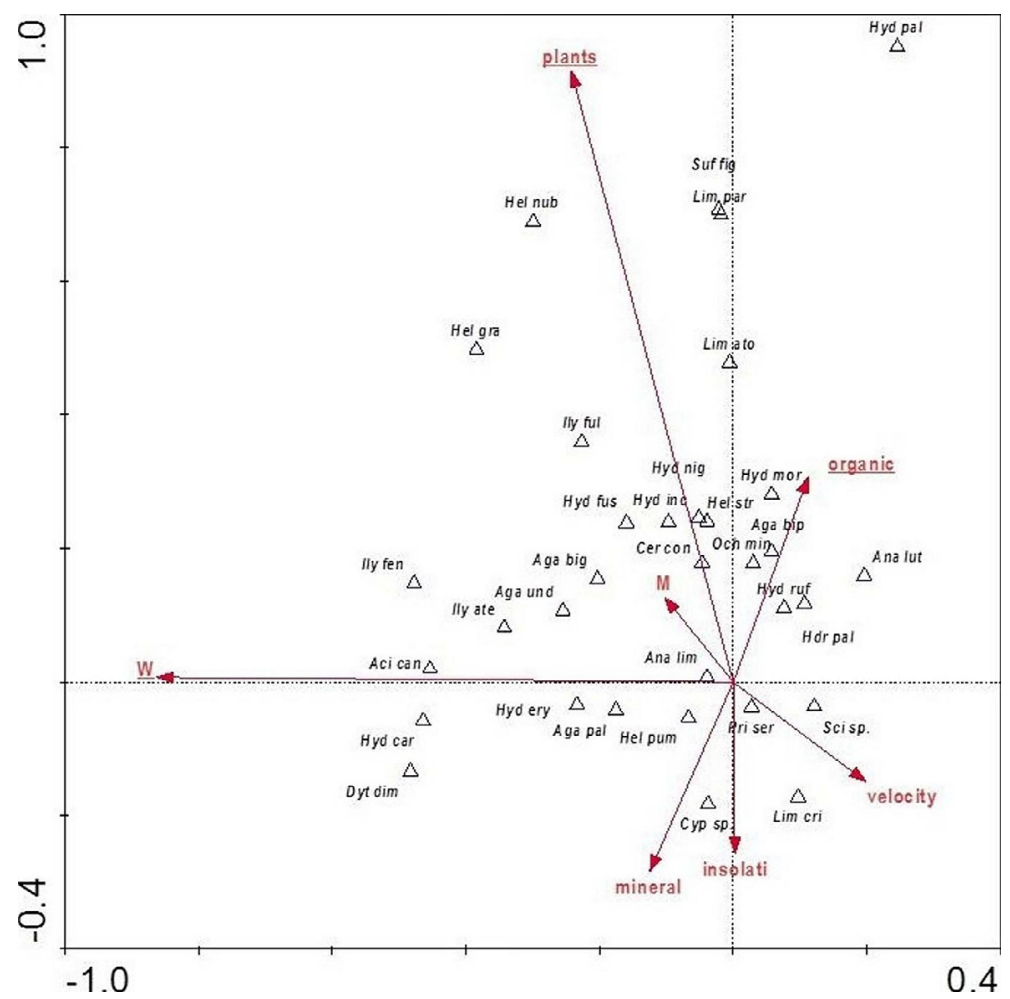

Fig. 7. Dependence of the occurrence of beetles on substrate structure, current velocity, plant cover and insolation.

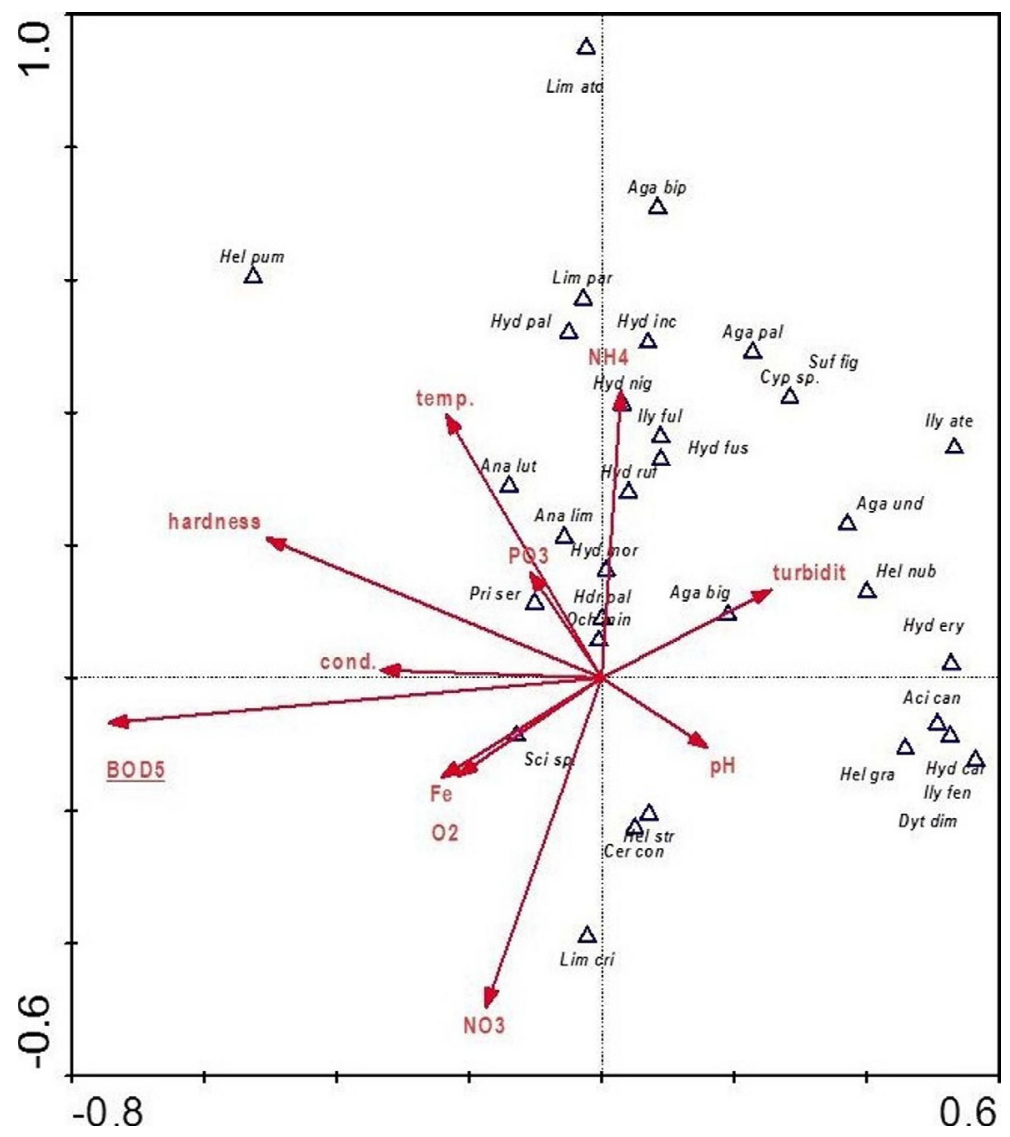

Fig. 8. Dependence of the occurrence of beetles on hydrochemical parameters. 


\section{Discussion}

Numerous studies on invertebrates inhabiting springs have shown that their species richness is generally low (Danks and Williams, 1991; Giller and Malmqvist, 1998; Smith and Gunn, 2003; Višinskienė and Bernotienè, 2013), although this does not apply to all taxonomic groups. The relatively low proportion of species most typical of springs is also emphasized (Danks and Williams, 1991; Roughley and Larson, 1991; Buczyński, 1999; Pakulnicka, 1999). This is true of aquatic beetles as well. Of the nearly 900 species known from Europe (Illies, 1978), only 59 are characterized as closely associated with springs, and only 6 are crenobionts (Pakulnicka, 1999). This is consistent with our data: despite the large number of species found in all of the springs of the Krapiel River valley in comparison with other spring systems that have been studied (Demel, 1922; Kordylas, 1994; Fisher, 1996; Pakulnicka, 1999; Czachorowski et al., 2000; Biesiadka and Pakulnicka, 2004; Pakulnicka and Nowakowski, 2012; Buczyński et al., 2003; Pakulnicka and Zawal, 2012; Trávníček, 2010; Višinskienė and Bernotienè, 2013), the species richness of individual springs was low. Moreover, stenotopes of this habitat, represented in the springs of the Krapiel River valley only by Agabus biguttatus, constituted a small proportion of their fauna. There were no other species typical of springs, most likely due to their lowland location.

In the valley of the Krapiel the most impoverished fauna with the lowest species diversity was noted in the rheocrenes, as in studies by Pakulnicka (1999). Species richness in the limnocrenes and helocrenes was markedly higher, and similar. The ecological composition of the fauna was also varied. Apart from eurytopic and stagnobiontic species, which generally have a greater quantitative and qualitative share in the fauna of springs (Pakulnicka, 1999), and species most specific for springs, we also find species closely associated with rivers (rheophiles and rheobionts) and with acidic peatbog waters (tyrphophiles and tyrphobionts). Our data show that the quantitative share of specialized species, including crenophiles, is nearly twice as high in limnocrenes as in helocrenes. Rheophiles also show greater species diversity here, while tyrphophiles had greater species richness in the helocrenes.

Differences in the structure of synecological elements in the fauna of springs of different limnological types have also been pointed out by Khmeleva et al. (1994), Czachorowski (1999), Pakulnicka (1999) and Buczyński et al. (2003). The type of spring, however, is not the only factor determining the structure of fauna assemblages. Many hydrobiologists draw attention to the effect of local environmental factors, such as substrate, current velocity, depth, character of surrounding vegetation, or physical and chemical parameters of the water (Khmeleva et al., 1994; Smith et al., 2003; Dumnicka et al., 2007; Křoupalová et al., 2011; Martin and Brunke, 2012).

Distribution of aquatic invertebrates largely depends on hydrochemical parameters. A characteristic of most springs is a constant low temperature and high oxygen content. The link between these factors and fauna, especially in rheocrenes and helocrenes, has been emphasized by researchers including Smith et al. (2003) and Tichá et al. (2012). While no such relationships are observed in the data from the valley of the Krapiel, this is certainly not because these factors were insignificant, but because the similar temperature and saturation of the water in all of the springs studied did not differentiate the species composition. On the other hand, the occurrence of beetles was strongly influenced by $\mathrm{BOD}_{5}$, which is usually significantly correlated with oxygen saturation and nutrients (Martin and Brunke, 2012; Pakulnicka et al., 2015b). Low values for this parameter were clearly conducive to high beetle species diversity and to the occurrence of species preferring less eutrophic water: rheophiles (the highest correlations with Ilybius fenestratus and Agabus paludosus), tyrphophiles (Ilybius ater and Hydroporus erytrocephalus), argillophiles (Helophorus nubilus), and crenophiles (Agabus biguttatus).

According to many hydrobiologists, factors shaping the landscape also significantly influence the character of macroinvertebrate fauna. These include geographical location (the most frequently mentioned element), the type of landscape, its structure (including the proximity of other water bodies), and how it is used (Castella et al., 1991; Delettre et al., 1992; Khmeleva et al., 1994; Richards and Host, 1994; Richards et al., 1996; Czachorowski, 1999; Pakulnicka, 1999; Delettre and Morvan, 2000; Dumnicka et al., 2007; Křoupalová et al., 2011; Martin and Brunke, 2012; Galic et al., 2013; Zawal et al., 2015a, 2015b). According to Pakulnicka (1999), faunistic differences between springs in different geographical locations are fairly pronounced, and are linked to climate, ecological landscape, or the proximity of other water bodies. The springs we studied, like other lowland springs, are characterized by greater species richness and a smaller percentage of stenotopes (crenobionts) than in mountain springs (Pakulnicka, 1999). The composition of the beetle fauna of the springs of the Krapiel valley, dominated by stagnobionts, indicates strong faunistic links between the springs and the small eutrophic water bodies dominating lowland landscapes. At the same time, the large percentage of rheophiles (mainly in the limnocrenes) and tyrphophiles (in limnocrenes and helocrenes) is indicative of migration of beetles from the nearby river and from acidic water bodies in forests. It should be emphasized that the faunistic relationships noted between the beetles inhabiting the springs of the valley are clearly asymmetrical, with other water bodies of the valley having a stronger effect on the springs than vice versa. In the valley of a river as small as the Krapiel, with no distinct floodplain, in which floods occur very seldom, these faunistic relationships take place mainly via dispersion by air.

The characteristics of aquatic environments that are potential donors of migrants should certainly have a considerable effect on the structure of the fauna of springs. Analysis of the hydromorphological parameters of the Krapiel River bed shows that the profile of the banks of the river plays a significant role. In springs situated near a steep bank, larger species that are good swimmers were generally dominant in the assemblages, while in others there were more poor swimmers keeping to the bottom, mainly of the genera Limnebius, Ochthebius, Helophorus, and Scirtes. This may be because the river by steep banks is usually deeper and flows faster. The structure of fauna in springs is also significantly influenced by the content of macrophytes and organic matter associated with them, as well as by grain-size sorting, which is linked to 
substrate structure. These factors proved particularly important for stagnobionts, which prefer habitats with moderate coverage by macrophytes and organic matter near the bottom, where they find not only shelter but usually abundant food sources.

For beetles, which have great potential to spread and disperse (Bilton, 1994; Lundkvist et al., 2002), particularly during unfavorable periods, landscape factors, such as landscape structure and use, should also be significant. The proximity of forests is undoubtedly important in the Krapiel valley, as they probably form a buffer zone preventing the flow of polluted groundwater to spring water, resulting in a low $\mathrm{BOD}_{5}$ value. This means that these habitats have not been substantially modified and have a high degree of naturalness, which as our data show - is conducive to the occurrence of more distinctive synecological elements comprising species preferring clean water that is not highly eutrophic, including crenophiles and rheophiles.

\section{Conclusions}

Lowland springs situated in the valley of the Krapiel River are an important element of the hydrological system of the river, reflecting its quality. Fairly diverse fauna is present in them, dominated by stagnobionts which penetrate them from other aquatic environments, mainly via dispersion by air. Another characteristic feature of the fauna is the small percentage of crenobionts and the substantial proportion of rheophiles and tyrphophiles, which is linked to the close proximity of the river and dystrophic water bodies. It is interesting that the characteristics of the spring fauna of the Krapiel valley were comparably influenced both by environmental factors acting on a local scale, such as hydrochemical parameters $\left(\mathrm{BOD}_{5}\right)$, and by landscape factors acting on a broader scale, particularly land-use structure (a large proportion of forests) and means of exploitation that do not lead to excessive habitat modification. This indicates the need for simultaneous analysis of both groups of factors.

Acknowledgements. We would like to thank Rafał Gosik for his assistance in identifying beetles of the superfamily Curculionoidea. The study was funded by the National Centre for Research and Development in Poland (Grant No. N305 222537).

\section{References}

Biesiadka E. and Pakulnicka J., 2004. Water beetles (Coleoptera) in Łomżyński Landscape Park of Valley of Narew River. Parki Nar. Rez. Przyr., 23, 427-447.

Bosi G., 2001. Abundance, diversity and seasonal succession of dytiscid and noterid beetles (Coleoptera: Adephaga) in two marshes of the Eastern Po Plain (Italy). Hydrobiologia, 459, 1-7.

Botosaneanu L., 1998. Studies in Crenobiology: The Biology of Springs and Springbrooks. Backhuys Publishers, Leiden, 261 p.
Buczyński P., 1999. Dragonflies (Odonata) of springs areas in Poland - state of research and proposes of further study, In: Biesiadka E. and Czachorowski S. (eds.), Springs in Poland, State of research, monitoring and protection, Wydawnictwo Wyższej Szkoły Pedagogicznej w Olsztynie Olsztyn, 31-36.

Buczyński P., Czachorowski S., Moroz M. and Stryjecki R., 2003. Odonata, Trichoptera, Coleoptera, and Hydrachnidia of Springs in Kazimierski Landscape Park (Eastern Poland) and factors affecting the characters of these ecosystems. Suppl. Acta Hydrobiol., 5, 13-29.

Cantonati M., Gerecke R. and Bertuzzi E., 2006. Springs of the Alps: sensitive ecosystems to environmental change: from biodiversity assessments to long-term studies. Hydrobiologia, 562, 59-96.

Castella E., Richardot-Coulet M., Roux C. and Richoux P., 1991. Aquatic macroinvertebrate assemblages of two contrasting floodplains: the Rhône and Ain rivers, France. Regul. Rivers. Res. Manage., 6, 289-300.

Costea G., Cojocaru I. and Pusch M., 2013. The Aquatic Beetles (Insecta: Coleoptera) assemblages in the Lower Prut Floodplain Natural Park (Romania). Natura Montenegr., 12, 719-736.

Czachorowski S., 1999. Caddisflies (Trichoptera) of Polish springs - the state of knowledge, In: Biesiadka E. and Czachorowski S. (eds.), Springs in Poland. State of research, monitoring and protection. Wydawnictwo Wyższej Szkoły Pedagogicznej w Olsztynie Olsztyn, 59-72.

Czachorowski S., 2004. The Last Natural Eastern River? Caddisflies (Trichoptera) of the Neman River. Latv. Entom., 41, 44-51.

Czachorowski S., Grużewski M. and Pakulnicka J., 2000. Caddis flies Trichoptera and water beetles Coleoptera from springs and runoffs in the vicinity of Drozdowo (north-eastern Poland). Przegl. Przyr., 11, 25-28.

Danks H.V. and Williams D.D., 1991. Arthropods of springs, with particular reference to Canada: synthesis and needs for research. Mem. Entomol. Soc. Can., 155, 203-217.

Di Sabatino A., Cicolani B. and Gerecke R., 2003. Biodiversity and distribution of water mites (Acari, Hydrachnidia) in spring habitats. Freshw. Biol., 48, 2163-2173.

Delettre Y.R. and Morvan N., 2000. Dispersal of adult aquatic Chironomidae (Diptera) in agricultural landscapes. Freshw. Biol., 44, 399-411.

Delettre Y.R., Tréhen P. and Grootaert P., 1992. Space heterogeneity, space use and short-range dispersal in Diptera: A case study. Landscape Ecol., 6, 175-181.

Demel K., 1922. Fauna zimowa w źródłach wigierskich. Pr. St. Hydrobiol. na Wigrach., 1, 1-25.

Dumnicka E., Galas J. and Koperski P., 2007. Benthic Invertebrates in Karst Springs: Does Substratum or Location Define Communities? Internat. Rev. Hydrobiol., 92, 452-464.

Eyre M.D., Foster G.N. and Foster A.P., 1992. Factors affecting the distribution of water beetle species assemblages in drains of eastern England. J. Appl. Entomol., 109, 217-225.

Foster G.N. and Eyre M.D., 1992. Classification Ranking of Water Beetle Communities. UK Nature Conservation, 1. Joint Nature Conservation Committee, Peterborough, 110 p.

Frelik A., 2014. Predation of adult large diving beetles Dytiscus marginalis (Linnaeus, 1758), Dytiscus circumcinctus (Ahrens, 
1811) and Cybister lateralimarginalis (De Geer, 1774) (Coleoptera: Dytiscidae) on fish fry. Oceanol. Hydrobiol. St., 43, 360-365.

Frelik A. and Pakulnicka J., 2015. Relations Between the Structure of Benthic Macro-Invertebrates and the Composition of Adult Water Beetle Diets from the Dytiscidae Family. Environ. Entomol., 44, 1348-1357.

Galic N., Hengeveld G.M., van den Brink P.J., Schmolke A., Thorbek P., Bruns E. and Baveco J.M., 2013. Persistence of Aquatic Insects across Managed Landscapes: Effects of Landscape Permeability on Re-Colonization and Population Recovery. PLoS ONE 8, e54584.

Giora M., 2014. Habitats. In: Donald Y. (ed.), Ecology, Systematics, and the Natural History of Predaceous Diving Beetles (Coleoptera: Dytiscidae), Springer, Netherlands, 307-363

Glazier D.S., 2009. Springs, In: Likens G.E. (ed.), Encyclopedia of inland waters, Vol. 1, Elsevier, Oxford, 735-755

Hoffsten P.O. and Malmqvist B., 2000. The macroinvertebrate fauna and hydrogeology of springs in central Sweden. Hydrobiologia, 436, 91-104.

Illies J., 1978. Limnofauna Europaea. A Checklist of the Animals Inhabiting European Inland Waters, with an Account of their Distribution and Ecology, 2nd Edition, Gustav Fischer Verlag, Stuttgart, $552 \mathrm{p}$.

Juliano S.A. and Lawton J.H., 1990a. The relationship between competition and morphology. I. Morphological patterns among cooccurring Dytiscidae Beetles. J. Anim. Ecol., 59, 403-419.

Juliano S.A. and Lawton J.H., 1990b. The relationship between competition and morphology. II. Experiments on co-occurring Dytiscidae Beetles. J. Anim. Ecol., 59, 831-848.

Khmeleva N., Nesterovich A. and Czachorowski S., 1994. The macroinvertebrate fauna of some Byelorussian, Karelian and Altaian springs and its relation with certain factors. Acta Hydrobiol., 36, 75-90.

Koch K., 1989, Die Käfer Mitteleuropas, Ökologie, Band 1, Goecke \& Evers, Krefeld.

Kordylas A., 1994. An investigation of the water beetles of Polish springs. Latissimus, 4, 9-11.

Křoupalová V., Bojková J., Schenková J., Pařil P. and Horsák M., 2011. Small-Scale Distribution of Aquatic Macroinvertebrates in Two Spring Fens with Different Groundwater Chemistry. Internat. Rev. Hydrobiol., 96, 235-256.

Kubíková L., Simon O.P., Tichá K., Douda K., Maciak M. and Bílý M., 2012. The influence of mesoscale habitat conditions on the macroinvertebrate composition of springs in a geologically homogeneous area. Freshw. Sci., 31, 668-679.

Martin P. and Brunke M., 2012. Faunal typology of lowland springs in northern Germany. Freshw. Sci., 31, 542-562.

Menetrey N., Sager L., Oertli B. and Lachavanne J.B., 2005. Looking for metrics to assess the trophic state of ponds. Macroinvertebrates and amphibians. Aquat. Conserv. Mar. Freshw. Ecosyst., 15, 653-664.

O'Hara R.B. and Kotze D.J., 2010. Do not log-transform count data. Meth. Ecol. Evol., 1, 118-122.

Pakulnicka J., 1999. The state of research on aquatic beetles (Coleoptera Aquatica) of springs in Poland, In: Biesiadka E. and Czachorowski S. (eds.), Springs in Poland. State of research, monitoring and protection, Wydawnictwo Wyższej Szkoły Pedagogicznej w Olsztynie Olsztyn, 149-155.

Pakulnicka J., 2008. The formation of water beetle fauna in anthropogenic water bodies. Oceanol. Hydrobiol. St., 37, 1-12.

Pakulnicka J. and Nowakowski J.J., 2012. The effect of hydrological connectivity on water beetles fauna in water bodies within the floodplain of a lowland river (Neman river, Belarus). Oceanol. Hydrobiol. St., 41, 7-17.

Pakulnicka J. and Zawal A., 2012. Water beetles (Coleoptera) of the "źródlisko Skrzypowe" nature reserve. Parki Nar. Rez. Przyr., 31, $11-20$.

Pakulnicka J., Górski A., Bielecki A., Buczyński P., Tończyk G. and Cichocka J.M., 2013. Relationships within aquatic beetle (Coleoptera) communities in the light of ecological theories. Fundam. Appl. Limnol., 183, 249-258.

Pakulnicka J., Buczyńska E., Buczyński P., Czachorowski S., Kurzạtkowska A., Lewandowski K., Stryjecki R. and Frelik A., 2015a. Are beetles good indicators of insect diversity in freshwater lakes? Oceanol. Hydrobiol. St., 44, 487-499.

Pakulnicka J., Górski A. and Bielecki A., 2015b. Environmental factors associated with biodiversity and the occurrence of rare, threatened, thermophilous species of aquatic beetles in the anthropogenic ponds of the Masurian Lake District). Biodiv. Conserv., 24, 429-445.

Przewoźny M., Buczyński P. and Mielewczyk S., 2006. Aquatic beetles (Coleoptera: Adephaga, Hydrophiloidea, Byrrhoidea) of the valley of the River Bug in the Lublin District (South-Eastern Poland). Nowy Pam. Fizjogr., 4, 23-54.

Richards C. and Host G., 1994. Examining land use influences on stream habitats and macroinvertebrates: a GIS approach. Water Res. Bull., 30, 729-738.

Richards C., Johnson L.B. and Host G., 1996. Landscape-scale influences on stream habitats and biota. Can. J. Fish. Aquat. Sci., 53, 295-311.

Roughley R.E. and Larson D.J., 1991. Aquatic Coleoptera of springs in Canada. Mem. Entomol. Soc. Can., 123, 125-140.

Smith H., Wood P.J. and Gunn J., 2003. The influence of habitat structure and flow permanence on invertebrate communities in karst spring systems. Hydrobiologia, 510, 53-66.

Tichá K., Simon O.P., Douda K. and Kubiková L., 2012. Detrital components in submontane organogenic springs in relation to their morphology, microhabitats and macroinvertebrates. Pol. J. Ecol., $60,163-175$.

Trávníček D., 2010. Water beetles of the meadow spring with tufa formation in the Bernice near Zlín SEI (Coleoptera: Haliplidae, Dytiscidae, Helophoridae, Hydrophilidae, Hydraenidae). Acta Carp. Occ., 1, 13-18.

Višinskienè G. and Bernotienè R., 2013. Macroinvertebrates in the south-eastern Lithuanian springs with the note on the blackfly (Diptera: Simuliidae) species new for Lithuanian fauna. New Rare Lithuania Ins. Sp. Rec. Descr., 25, 73-78.

Williams D.D. and Williams N.E., 1998. Invertebrate communities from freshwater springs: what can they contribute to pure and applied ecology?, In: Botosaneanu L. (ed.), Studies in crenobiology, The Biology of Springs and Springbrooks, Backhuys Publishers, Leiden, 251-261. 
Williams D.D., Williams N.E. and Cao Y., 1997. Spatial differences in macroinvertebrate community structure in southeastern Ontario in relation to their chemical and physical environments. Can. J. Zool., 75, 1404-1414.

Winfield Fairchild G., Faulds A.M. and Matta J.F., 2000. Beetle assemblages in ponds: effects of habitat and site age. Freshw. Biol., 44, 523-534.

Zawal A., Czachorowski S., Stępień E., Buczyńska E., SzlauerŁukaszewska A., Buczyński P., Stryjecki R., Dąbrowski P., 2015a. Early post-dredging recolonization of caddisflies (Insecta: Trichoptera) in a small lowland river (NW Poland). Limnology, $17,71-85$.
Zawal A., Stępień E., Szlauer-Łukaszewska A., Michoński G., Kłosowska M., Bańkowska A., Myśliwy M., Stryjecki R., Buczyńska E. and Buczyński P., 2015b. The influence of a lowland river dredging (the Krapiel in NW Poland) on water mite fauna (Acari: Hydrachnidia). Fundam. Appl. Limnol., 186, 217 232.

Zollhöfer J.M., 1997. Quellen - die unbekannten Biotope im Schweizer Jura und Mittelland: erfassen, bewerten, schützen, Bristol-Schriftenreihe Band 6, Bristol-Stiftung, Ruth und Herbert Uhl Forschungsstelle für Natur- und Umweltschutz, Zürich, $153 \mathrm{p}$.

Cite this article as: J. Pakulnicka, P. Buczyński, P. Dąbkowski, E. Buczyńska, E. Stępień, R. Stryjecki, A. Szlauer-Łukaszewska, A. Zawal, 2016. Aquatic beetles (Coleoptera) in springs of a small lowland river: habitat factors vs. landscape factors. Knowl. Manag. Aquat. Ecosyst., $417,29$. 